\title{
Higher Education Objectives Impact towards the Attainment of Cameroon's Vision 2035 with Respect to Poverty Alleviation, and National Unity and Consolidation of Democracy
}

\author{
Awu Isaac Oben (1) \\ Faculty of Education, Southwest University, Chongqing, China \\ Email: isaacoben87@gmail.com
}

How to cite this paper: Oben, A.I. (2021) Higher Education Objectives Impact towards the Attainment of Cameroon's Vision 2035 with Respect to Poverty Alleviation, and National Unity and Consolidation of Democracy. Open Access Library Journal, 8: e7576.

https://doi.org/10.4236/oalib.1107576

Received: May 24, 2021

Accepted: June 27, 2021

Published: June 30, 2021

Copyright $\odot 2021$ by author(s) and Open Access Library Inc.

This work is licensed under the Creative Commons Attribution International License (CC BY 4.0).

http://creativecommons.org/licenses/by/4.0/

\begin{abstract}
Higher Education in the Cameroon context is assigned a basic mission of producing, Organizing and disseminating scientific, cultural, professional and ethical knowledge for development purposes. This study aimed at investigating the extent to which the Implementation of Higher Education Objectives (HEO) predicts the attainment of Cameroon's Vision 2035. Specifically, the study was: 1) To find out whether the promotion of ethics and national consciousness is effectively facilitating the attainment of Cameroon's Vision 2035 with respect to poverty alleviation, and national unity and consolidation of democracy; 2) To find out whether the promotion of bilingualism is effectively ensuring the attainment of Cameroon's Vision 2035 with respect to poverty alleviation, and national unity and consolidation of democracy. The study made use of two hypotheses, which were either accepted or rejected after analysis. The quantitative and qualitative (mixt method) design was used for this study. The population of the study consisted of all the final year students (potential graduates: B.Sc, B.Ed, M.A, M.Sc, M.Ed, Ph.D, and HND etc.) from 14 Higher Institutes of Learning (HIL) in the South West Region of Cameroon. The sample consisted of 370 students chosen at random. 24 teachers were also interviewed. A questionnaire and an interview guide were used for data collection. The questionnaire was validated by 30 students who did not constitute part of the sample. Quantitative data were analyzed using the Pearson Product Moment Correlation Coefficient (statistical tool). Qualitative data were analyzed by using content analysis. The main findings revealed that; the current promotion of ethics and national consciousness is high, hence guarantees the attainment of Cameroon's Vision 2035 with respect to poverty alleviation, and national unity and consolidation of democ-
\end{abstract}


racy. On the contrary, the mean for the current promotion of bilingualism was found low as such does not guarantee the attainment of Cameroon's Vision 2035 with respect to poverty alleviation, and national unity and consolidation of democracy. The researcher concluded that the Implementation of HE Objectives has a direct relationship with the attainment of Cameroon's Vision 2035 yet some of the objectives are not effectively implemented. Some recommendations were made.

\section{Subject Areas}

Education

\section{Keywords}

Higher Education Objectives, Implementation, Bilingualism, Ethics, Poverty Alleviation, National Consciousness, Cameroon's Vision 2035

\section{Introduction}

The greatest investment any nation can make is believed to be the one committed to the training of her citizens, who will consequently develop the nation because education is a priority of priorities, a means to an end and not an end in itself (Mbua 2003 [1], Ojong 2008 [2], World Bank 2009 [3], Doh, 2012 [4] and United Nations (2015) [5]. That's why, UNESCO (1998) [6], earlier pointed out that, a country cannot develop without the contribution of its education system. For instance, Higher Education (HE) is the only sector that can comparably claim to be second only to the state government (Fuller, cited in Doh 2012 [4]). Paradoxically it is the only sector that is all-powerful and ubiquitous in the development of all the other sectors, even though it is simply an educational sub-sector. It fits and intervenes to develop every sector. Traditionally HE has been assigned multiple roles to produce human capital for national development, widen access, provide citizen education, drive national social inclusion policies, develop the agricultural sector, mining, health, women's emancipation and gender equality, national defense, the lower educational cycles and many other sectors through embodied knowledge, research, training and capacity-building. Recently Globalization and changes in the structure of economies and national policies like Cameroon's vision 2035 have introduced new pressures for HE to prove its worth and provide quality education and research for innovation and competitiveness of nations and at the same time, respond to its immediate regional development needs (Doh, 2012) [4]. Also, HE increases the employability profiles of graduates and creates opportunities for their insertion in academic jobs (SUP INFOS 2010) [7]. If the aforementioned assessments are valid, then Cameroon's vision 2035 (An Emerging, Democratic and United Country in Diversity) greatly depends on sectors like HE for its attainment (Ngwane, 2009) [8]. And for such correlation to smoothly occur, HE needs to set 
higher standards (Meek, 1993) [9]. Higher Education objectives (HEO) must be clear, comprehensive, realistic, and effectively implemented, for learners/graduates to possess the necessary quality skills, knowledge and attitude, which are sustainable and beneficial to the individual and the nation's development at large. Based on the current state of HE in Cameroon in relation to Vision 2035, there is a need to investigate the level of the implementation of the Objectives stated in Law No.005 of 16 April 2001 to Guide HE. Considering that, the level of implementation may predict the attainment of Cameroon's Vision 2035.

\subsection{Research Context}

The Republic of Cameroon is a triangular shape covering an area of $475,650 \mathrm{~km}$ on the armpit of the map of Africa, between West and Central Africa. Cameroon has a population of 19,406,100 inhabitants with an annual population growth rate of 2.6 percent (2009 Census; United Nations Population Fund, UNFPA cited in Doh, 2012 [4]). The country is divided into 10 regions, eight (8) and two (2) of which are respectively French and English-speaking. As a former French and British colony, it runs a bicultural Francophone and Anglo-Saxon educational and administrative systems. It is a bilingual country; its official languages being French and English which are used as medium of instruction from the basic through tertiary education. Cameroon operates within an economic and monetary zone of six countries, the Economic Community of Central African States (CEMAC) (Doh, 2012) [4]. The Cameroon HE is composed of eight (8) state owned universities and a private sector of many higher institutions, where English or French or both (bilingual status) are used as a medium of instruction (Doh, 2012) [4]. HE in Cameroon have the responsibility to ensure that vision 2035 is attained based on its strategic position and aforementioned advantages.

This study delimited it content scope to the HEO in Cameroon and attainment of vision 2035. According to Doh (2015) [10] Objectives refers to the desired change that an individual, organization or institution is trying to achieve, or the intended outcomes of an institution. Like any other sector, HEO in Cameroon has undergone a lot of developmental transformation and policy implementation and amendments since its birth in 1960 depending on the needs of each period (Fonkeng, 2007) [11]. For instance, after independence there was need to coin education to suit the needs of Cameroon; like bilingualism, ruralization or back to land as well as efficiency, solidarity and respect of human nature and human personality as in Communal Liberalism of Biya in 1984. Tambo (2003) [12] remarked that, the Cameroon's 1995 Educational Forum was the largest gathering on education in Cameroon since independence. This forum was the "landmark in Educational Development of Cameroon as it marked the start of more concerted efforts to formulate National Education Policy in a more formal manner" Given the several problems faced and failures recorded by Cameroon's Educational System since independence, the general objective of this 
forum was to adopt an educational policy which will help Cameroon take up the challenge of the $21^{\text {st }}$ century and solve the major problems plaguing the Cameroon society. This ramified around political, economic, social and cultural factors of the country. Following recommendations by the 1995 forum, let to the passing of the law $\mathrm{N}^{\circ} 98 / 004$ of $14^{\text {th }}$ April 1998 to Lay down Guidelines for Education in Cameroon (MINEDUC (1998) [13]. Part I of the law spells out in Section 4 specified that: "the general purpose of education shall be to train children (students) for their intellectual, physical, civic and moral development and their smooth integration into society bearing in mind prevailing economic, socio-cultural, political and moral factors" The passing of this law have led to many other laws on education in Cameroon. For example the stipulation of Law No. 005 of 16 April 2001 to Guide HE in Cameroon which is the current HEO and main focus of this study.

The current missions and objectives apportioned to HE in Cameroon are stipulated by the Ministry of Higher Education (MINESUP). They emanate from the laws $\mathrm{N}^{\circ}$. 98/004 of $4^{\text {th }}$ April 1998 providing orientation of Education in Cameroon and law $\mathrm{N}^{\circ} .005$ of $16^{\text {th }}$ April 2001 to guide HE following successive reforms (Tambo, 2003, p. 285 [12], and Tchombe, 2001, [14]) Part I focuses on the General Provisions in which Article 2: of part 1 states that, "HE shall be assigned a basic mission of producing, organizing and disseminating scientific, cultural, professional and ethical knowledge for development purposes" (MINESUP, 2001) [15]. Part 1; (2) of the of the aforementioned law recognizes that " $H E$ shall comprise all the post-secondary training courses taught by public higher education institutions and private education institutions approved by the State as higher education institutions”. To reiterate Cameroon's bilingual status, Article 5: emphasized that, "in HE, the State shall ensure that bilingualism is a factor for unity and national integration" Chapter I: focuses on HEO which are stated in Article 6: (1). The basic mission of the HE realm stipulated in article 2 above have a number goals, but for the purposes of this study, two were selected for investigation because of their direct relationship with vision 2035, they include: (1) The deepening of ethics and national consciousness and (2) The promotion of bilingualism.

Furthermore, Cameroon's Vision by 2035 is to become; An Emerging, Democratic and United Country in Diversity, (MINEPAT2009) [16]. This vision came up as a result of the Poverty Reduction Strategy Paper (PRSP) of 2003. MINEPAT report of 2009 showed that the Government of Cameroon was able to maintain a stable macroeconomic framework and sustain positive growth rates up to 2008 by implementing the PRSP adopted in April 2003. The vision focuses on the identification of the population's needs, aspirations and the ambitions of politicians. The determination to become an emerging country calls for a number of key objectives, namely: 1) reducing poverty to socially acceptable levels; 2) becoming a middle-income country; 3) becoming a newly industrialized country; 4) consolidating democracy and enhancing national unity (MINEPAT, 2009, 
p. 15) [16]. For the purpose of this study, general objective number one (Poverty Alleviation) and four (Reinforcing National Unity and Consolidating the Democratic Process) were selected for this study based on their direct relationship with HEO.

With regards to poverty alleviation, Cameroon is asserting its desire to see the incidence of poverty drop below $1 / 10$, that is to say; only one of every 10 Cameroonians would still be poor by 2035 (GESP, 2009) [17]. The reduction of income poverty would lead to and ensure greater access to good quality social services such as improved access to healthcare, education, training services, other basic infrastructures ( energy, road and portable water supply) and working for the elimination of disparities (MINEPAT, 2009) [16]. While Reinforcing National Unity and Consolidating the Democratic Process is a determination that Cameroon, united in diversity will be a country in which unity and integration are visible in the respect of differences and identities. Whereby Values such as the respect of authority, cohesion, solidarity, integrity, regions, ethnic groups, cultures, generations, sex, social, intellectual, civil and military classes, corporations, opinions and religions, work and pride will be watchwords for individual and collective behaviors. And the State affairs will be run on the basis of consultations, dialogue, tolerance, and mutual respect, recourse to mediation or justice. The safety and security of persons and property will be ensured nationwide. The foundations of peace and democracy are freedom, equality and the sovereignty of the people of Cameroon. More MINEPAT (2009) [16] maintains that Cameroon, democratic country, will be a State with stable institutions and effective separation of powers. The Judiciary will be truly independent and based on an amended and modified justice system tailored to local values and the economic context. The Cameroonian State will be powerful, sovereign, a catalyst of economic and social progress, and its authority will rest on popular legitimacy. It will be respectful of individual and collective freedoms. It will have a well-equipped and decentralized administration, qualified and motivated human resources.

Based on Education and training expectations, vision 2035 hopes that; Cameroon will have to enhance education and the training of human resources in the fields of health, science and technology, among others. The objective will be, notably in the health sector to evolve from 7 medical doctors for every 100,000 people to 70 medical doctors for every 100,000 people. Similar initiatives should be taken as concerns teachers training in all cycles and training of engineers (ICT, civil engineering, petro chemistry, mining, process engineering, agronomy, animal industries, etc). In order to improve youth employability, it is urgent to increase in secondary school and higher education, the rate of students enrolled in scientific and technological courses notably from the current 5 percent to 30 percent by 2035. To achieve such ambition, bold actions are required to ensure early guidance and counselling of children, and use new techniques for knowledge communication as well as further training (MINEPAT, 2009) [16]. 
Following this point of view, HE has a lot to play in the attainment of Cameroon's vision 2035 given that their mission and objectives both align towards Cameroon's development.

\subsection{Statement of the Problem}

Higher Education Objective calls for distinguished acquisition of quality skills, knowledge and attitude by its graduates, yet the link seems to be farfetched as most learners from professional and general higher education institution cannot effectively demonstrate their skills, knowledge and attitude after graduation. Experience and observation has shown that, most graduates from HE are less productive and have little to offer to the nation's rapid development. This happens probably because they lack the required skills, knowledge and attitude. Consequently a significant percentage of about $70 \%$ graduates constitute a high dependency ratio (job seekers instead of job creators and problem solvers). Contrary to Article 2 of Law $\mathrm{N}^{\circ} .005$ of 16 April 2001, to guide HE in Cameroon which stated that, "The HE realm shall be assigned a basic mission of producing, organizing and disseminating scientific, cultural, professional and ethical knowledge for development purposes" (MINESUP, 2001) [15] and the anticipated dream of 2009 to transform Cameroon into an Emerging, Democratic and United Country in Diversity by 2035 (MINEPAT, 2009) [16]. The wide gap that exists in the area of; professionalism, bilingualism, gender equality, research, industrialization, poverty, corruption, embezzlement, tribalism, nepotism, crime waves, democracy, peace and national unity just to name a few. These aspects do not reflect the HEO, hence a call for concern. The problem with HEO seems to lie in its implementation such as the ineffective teaching-learning process which leaves most graduate with unprofessional, mediocre and pedestrian skills, knowledge and attitudes. It is as a result of little efforts employed in research and monitoring of this relationship since 2001 that provoked the researcher to investigate the relationship that exists between the implementation of HEO and the attainment of Cameroon's Vision 2035 with respect to poverty alleviation, and national unity and consolidation of democracy.

\subsection{Objectives of the Study}

The purpose of this study was to investigate the level implementation of Higher Education Objectives (HEO) on the attainment of Cameroon's Vision 2035 with respect to poverty alleviation, and national unity and consolidation of democracy.

\section{Specific Objectives of the Study}

1) To find out whether the promotion of ethics and national consciousness is effectively facilitating the attainment of Cameroon's Vision 2035 with respect to poverty alleviation, and national unity and consolidation of democracy.

2) To find out whether the promotion of bilingualism is effectively ensuring the attainment of Cameroon's Vision 2035 with respect to poverty alleviation, 
and national unity and consolidation of democracy.

\subsection{Research Questions}

To what extent does the implementation of HEO ensure the attainment of Cameroon's Vision 2035 with respect to poverty alleviation, and national unity and consolidation of democracy?

\section{Specific Research Questions}

1) To what extent does the promotion of ethics and national consciousness facilitate the attainment of Cameroons vision 2035 with respect to poverty alleviation, and national unity and consolidation of democracy?

2) To what extent does the promotion of bilingualism ensure the attainment of Cameroons vision 2035 with respect to poverty alleviation, and national unity and consolidation of democracy?

\subsection{Hypotheses}

This study was guided by two hypothesis. In subsequent readings, the scores obtained from this will be analyzed, and interpreted to accept or reject each of the null hypotheses guiding this study. They hypothesis includes:

$\mathrm{H}_{\mathrm{ol}}$ : There is no significant relationship between the promotion of ethics and national consciousness, and the attainment of Cameroon's Vision 2035 with respect to poverty alleviation and national unity and consolidation of democracy.

$\mathrm{H}_{\mathrm{a} 1}$ : There is a significant relationship between the promotion of ethics and national consciousness, and the attainment of Cameroon's Vision 2035 with respect to poverty alleviation and national unity and consolidation of democracy.

$\mathrm{H}_{\mathrm{o} 2}$ : There is no significant relationship between the promotion of bilingualism and the attainment of Cameroons Vision 2035 with respect to poverty alleviation and national unity and consolidation of democracy.

$\mathrm{H}_{\mathrm{a} 2}$ : There is a significant relationship between the promotion of bilingualism and the attainment of Cameroons Vision 2035 with respect to poverty alleviation and national unity and consolidation of democracy.

\section{Method and Procedure}

\subsection{Research Design}

The cross sectional survey research design was used for this study, adopting both the quantitative and qualitative approaches (a mixed-method design). According to Amin (2005) [18]. Survey research involves the collection of information from sample individuals through their responses to questions.

\subsection{Population of the Study}

The population of this study comprised of all the final year students and teachers (instructors) of Higher Institutions of Learning (HIL) both public and private in the Fako and Meme Divisions. The target population was made up of 24,000 
students and 300 teachers of HIL. The accessible population constituted of 13623 final year students (potential graduates: B.Sc, B.Ed, M.A, M.Sc, M.Ed, Ph.D, and HND etc.) and 252 teachers of HIL in the Fako and Meme Divisions, both public and private. The Accessible Population of this study involved students and teachers from 14 HIL in the Fako and Meme Divisions; (4 public and10 private).

\subsection{Sample and Sampling Technique}

The sample population was made up of 370 students, and 28 teachers. This sample was chosen proportionately to the total population as recommended by Krejcie and Morgan (1970) [19]. The sample of this study was made up of representative students and teachers from the 14 accessible HIL in the South West Region. The simple random sampling technique was use for this study. Fourteen (14) Higher Institutes were selected using the simple random sampling, four (4) public and ten (10) private (2 Denominational and 8 Lay Private) institutions. For clarity purposes, a sampling technique according to Mbiko (1990, p. 36) [20]. refers to the mechanical methods used to select sample from a population.

\subsection{Instrumentation}

A questionnaire which was designed by the researcher was used as the main instrument for data collection, accompanied by an interview guide for teacher. Guided by review of literature, the questionnaire items were developed by the researcher to address the specific objectives of the study. The questionnaire was made up of closed ended opinion statements with a total of twenty eight (28) items. All the opinion statements were rated on a 4-point Likert-type scale (alternative responses) ranging from "Strongly Agree" (SA), "Agree" (A), "Disagree" (D), to "Strongly Disagree" (DA). 370 questionnaire copies were administered. 28 teachers were interviewed using the interview guide prepared for the study. The interview guide was constructed with guiding questions based on the research questions to find out from teachers the relationship of the research variables (dependent and independent). The Instrument Validity (face and content) and reliability was taken into proper consideration. The questionnaire was validated by 30 students who did not constitute part of the sample.

\subsection{Administration of the Instrument}

The researcher employed the services of two research assistants. The assistants were trained on how to administer and collect data as well as the appropriate behavior required. A daily plan of activities was drawn and the researcher and the assistants visited at least 2 HIL a day. The researcher and the assistants guided the respondents and personally administered the instruments to them face to face to ensure consistency, avoid errors and ensured a favorable returned rate.

\subsection{Procedure for Data Analysis}

Descriptive and inferential statistics were used for data analysis. The statistical 
tool used for analysis was the Pearson Product Correlation Moment Analysis (PPMCA). The formula using deviation from the mean method was:

$$
\Gamma_{x y}=\frac{\sum(x-\bar{x})(y-\bar{y})}{\sqrt{\sum(x-\bar{x})^{2} \sum(y-\bar{y})^{2}}}
$$

where $x$ is the independent variable, $y$ is the dependent variable and $\Gamma_{x y}$ is the correlation coefficient for $x$ and $y$.

\section{Results}

The results of the statistical analyses of data gathered for this study are presented here. The presentation of the data was done following the trends of the two hypotheses directing the study.

\subsection{Return Rate of Questionnaire}

Out of the 370 questionnaires administered, 363 were returned which revealed a favorable returned rate of $98.1 \%$ as shown in Table 1 .

\subsection{General Description of Data/Variable}

The main independent variable of this study was the implementation of Higher Education Objectives while the main dependent variable was the attainment of Cameroon's vision 2035 with respect to poverty alleviation, and national unity and consolidation of democracy. Descriptive data analysis for all variables in the study are presented below (Table 2).

The scores obtained were analyzed, presented and interpreted to accept or reject each of the two null hypotheses guiding this study.

Table 1 . The return rate of questionnaire.

\begin{tabular}{cccc}
\hline School Type & $\begin{array}{c}\mathbf{N}^{\bullet} \text { of Questionnaire } \\
\text { Distributed }\end{array}$ & $\begin{array}{c}\mathbf{N}^{\bullet} \text { of Questionnaire } \\
\text { Returned }\end{array}$ & $\begin{array}{c}\text { Percentage } \\
\text { Returned }\end{array}$ \\
\hline Public & 153 & 148 & 40 \\
Denominational & 45 & 45 & 12.16 \\
Lay private & 172 & 170 & 45.94 \\
Total & 370 & 363 & 98.10 \\
\hline
\end{tabular}

Table 2. Means and standard deviations of all variables in the study.

\begin{tabular}{ccccc}
\hline VARIABLES & $\begin{array}{c}\mathbf{N}^{\bullet} \\
\text { of respondents }\end{array}$ & $\begin{array}{c}\mathbf{N}^{\bullet} \\
\text { of items }\end{array}$ & Mean & $\begin{array}{c}\text { Std. } \\
\text { Deviation }\end{array}$ \\
\hline $\begin{array}{c}\text { Promotion of ethics and } \\
\text { national consciousness }\end{array}$ & 363 & 8 & 20.17 & 5.63 \\
$\begin{array}{c}\text { Promotion of Bilingualism } \\
\text { Poverty Alleviation }\end{array}$ & 363 & 8 & 12.89 & 4.90 \\
$\begin{array}{c}\text { National Unity and } \\
\text { Consolidation of Democracy }\end{array}$ & 363 & 6 & 16.91 & 3.75 \\
\hline
\end{tabular}




\subsection{Data Analysis and Interpretation}

$\mathrm{Ho}_{1}$ : There is no significant relationship between the promotion of ethics and national consciousness, and the attainment of Cameroon's Vision 2035 with respect to poverty alleviation and national unity and consolidation of democracy.

As shown in Table 3, the result of the analysis revealed that the calculated $\Gamma_{x y}$-value of 0.33 for poverty alleviation and 0.50 for national unity and consolidation of democracy are both greater than the critical $\Gamma_{x y}$-value of 0.113 at 0.05 level of significance with 361 degrees of freedom. With the result of the analysis, the null hypothesis was rejected and the alternative hypothesis retained for the attainment of Cameroon's Vision 2035 with respect to both poverty alleviation and the strengthening of national unity and consolidation of democracy. This result therefore means that the current promotion of ethics and national consciousness is high and also guarantees the attainment of Cameroon's Vision 2035 with respect to poverty alleviation and national unity and consolidation of democracy.

$\mathrm{Ho}_{2}$ : There is no significant relationship between the promotion of bilingualism and the attainment of Cameroon's Vision 2035 with respect to poverty alleviation and national unity and consolidation of democracy.

As shown in Table 4, the result of the analysis reveals that the calculated $\Gamma_{x y}$-value of 0.26 for poverty alleviation and 0.43 for national unity and consolidation of democracy are both greater than the critical $\Gamma_{x y}$-value of 0.113 at 0.05 level of significance with 361 degrees of freedom. With the result of the analysis, the null hypothesis was rejected and the alternative hypothesis retained for the attainment of Cameroon's Vision 2035 with respect to both poverty alleviation and the strengthening of national unity and consolidation of democracy. However the mean score for the promotion of bilingualism is low (12.89 on 32) This result therefore means that with the present state of the promotion of bilingualism vision 2035 may not be attained with respect to poverty alleviation and national unity and consolidation of democracy.

Table 3. PPMCA of the influence of extent of promotion of ethics and national consciousness, and the attainment of Cameroon's Vision 2035 with respect to poverty alleviation and national unity and consolidation of democracy $(\mathrm{N}=363)$.

\begin{tabular}{|c|c|c|c|c|}
\hline \multirow{3}{*}{ Variable } & $\sum X$ & $\sum X^{2}$ & & \\
\hline & $\sum Y_{1}$ & $\sum Y_{1}^{2}$ & $\Sigma X Y_{1}$ & $\Gamma_{x y 1}$ \\
\hline & $\sum Y_{2}$ & $\sum Y_{2}^{2}$ & $\Sigma X Y_{2}$ & $\Gamma_{x y 2}$ \\
\hline $\begin{array}{l}\text { extent of Promotion of Ethics and } \\
\text { National Consciousness }(X)\end{array}$ & 7322 & 159,154 & & \\
\hline Poverty Alleviation $\left(Y_{1}\right)$ & 6137 & 108,837 & 126,328 & $0.33^{\star}$ \\
\hline $\begin{array}{c}\text { National Unity and Consolidation } \\
\text { of Democracy }\left(Y_{2}\right)\end{array}$ & 6204 & 111,490 & 129,085 & $0.50^{\star}$ \\
\hline
\end{tabular}


Table 4. PPMCA of the influence of extent of promotion of bilingualism, and the attainment of Cameroon's Vision 2035 with respect to poverty alleviation and national unity and consolidation of democracy $(\mathrm{N}=363)$.

\begin{tabular}{|c|c|c|c|c|}
\hline \multirow{3}{*}{ Variable } & $\Sigma X$ & $\Sigma X^{2}$ & & \\
\hline & $\sum Y_{1}$ & $\sum Y_{1}^{2}$ & $\sum X Y_{1}$ & $\Gamma_{x y 1}$ \\
\hline & $\sum Y_{2}$ & $\sum Y_{2}^{2}$ & $\Sigma X Y_{2}$ & $\Gamma_{x y 2}$ \\
\hline extent of Promotion of bilingualism $(X)$ & 4022 & 97,048 & & \\
\hline Poverty Alleviation $\left(Y_{1}\right)$ & 6137 & 108,837 & 72,187 & $0.26^{*}$ \\
\hline $\begin{array}{l}\text { National Unity and Consolidation } \\
\text { of Democracy }\left(Y_{2}\right)\end{array}$ & 6204 & 111,490 & 75,995 & $0.43^{\star}$ \\
\hline
\end{tabular}

$\mathrm{p}^{*}<0.05 ; \mathrm{df}=361 ;$ critical $\Gamma_{x y}=0.113$.

\subsection{Description Analysis of Responses from the Interview}

This section is concern with results obtained from interview conducted in this study. The following are teachers' responses;

Table 5 indicates that, $83.33 \%$ of respondents said that they usually encourage the promotion of ethics and national consciousness with a common option of sensitizing and teaching ethical values and national diversities to their learners while $16.67 \%$ revealed that, they do not encourage the implementation of ethics and national consciousness because it is not part of their teaching subjects/curriculum as such it is a waste of time.

Table 6 indicates that, $70.83 \%$ of respondents said that they usually encourage the promotion of bilingualism with a common option of speaking to and teaching/evaluating the learners in the two official languages (English and French) based on their diversities while $29.17 \%$ revealed that, they do not encourage the implementation of bilingualism because they themselves are not bilingual; they teach using the language they are versed with and do not evaluate learners in English and French.

Table 7 indicates that $75 \%$ of respondents said that their school encourages poverty alleviation. This is because they offer courses in entrepreneurship, resource management, banking and accountancy compulsory to students; as such student will have necessary skills for self-employment. On the contrary $25 \%$ revealed that, their institutions do not encourage poverty alleviation because their institutions do not offer courses in entrepreneurship, resource management, banking and accountancy compulsory to students, as such some student may not have necessary skills for self-employment.

Table 8 indicates that $83.33 \%$ of respondents said that their school encourages the strengthening of national unity and consolidation of democracy. This is because they encourage the creation of student's association, organizes games, send students on internship, and treat students from different cultural diversity equally. On the other hand $16.67 \%$ revealed that, their institutions do not encourage the strengthening of national unity and consolidation of democracy because they do not encourage the creation of student's association, organizes 
Table 5. Description of Respondents on whether teachers in HIL encourage the promotion of ethics and national consciousness and their role played in implementing it.

\begin{tabular}{ccccc}
\hline Responses & \multicolumn{2}{c}{ Frequency } & Total & Percentage \\
\hline \multirow{2}{*}{ Yes } & Male & Female & & \\
& 10 & 10 & 20 & 83.33 \\
No & 2 & 2 & 4 & 16.67 \\
Total & 12 & 12 & 24 & 100 \\
\hline
\end{tabular}

Table 6. Description of Respondents on whether teachers in HIL encourage the promotion of bilingualism and their role played in implementing it.

\begin{tabular}{ccccc}
\hline Responses & \multicolumn{2}{c}{ Frequency } & Total & Percentage \\
\hline Yes & Male & Female & & \\
& 8 & 9 & 17 & 70.83 \\
No & 4 & 3 & 7 & 29.17 \\
Total & 12 & 12 & 24 & 100 \\
\hline
\end{tabular}

Table 7. Description of Respondents on whether HIL encourage poverty alleviation and role played by teachers in implementing it.

\begin{tabular}{ccccc}
\hline Responses & \multicolumn{2}{c}{ Frequency } & Total & Percentage \\
\hline \multirow{2}{*}{ Yes } & Male & Female & & \\
& 9 & 9 & 18 & 75 \\
No & 3 & 3 & 6 & 25 \\
Total & $\mathbf{1 2}$ & $\mathbf{1 2}$ & $\mathbf{2 4}$ & $\mathbf{1 0 0}$ \\
\hline
\end{tabular}

Table 8. Description of Respondents on whether HIL encourage the strengthening of national unity and consolidation of democracy and role played by teachers in implementing it.

\begin{tabular}{ccccc}
\hline Responses & \multicolumn{2}{c}{ Frequency } & Total & Percentage \\
\hline \multirow{2}{*}{ Yes } & Male & Female & & \\
& 10 & 10 & 20 & 83.33 \\
No & 2 & 2 & 4 & 16.67 \\
Total & 12 & 12 & 24 & 100 \\
\hline
\end{tabular}

games, send students and finally do not treat students from different cultural diversity equally.

\section{Discussion of Findings}

Results revealed that, there is a direct relationship between promotion of ethics and national consciousness and Cameroon's vision 2035 with respect to poverty alleviation, and national unity and consolidation of democracy. The result of the analysis indicated that the current promotion of ethics and national consciousness is high in HE and also guarantees the attainment of Cameroon's Vision 2035 with respect to poverty alleviation, and national unity and consolidation of 
democracy. In addition the results implies that if ethics and national consciousness is continually implemented and improved in all HIL, then Cameroon's Vision 2035 will be attained duly. The results are in line with, Durkheim cited in Tambo (2000, p. 235) [21] who argued that, the school (HE) comes next to the family and the church, as the only moral agent through which the learner is able to systematically learn ethical/moral education to know and love his or her country. From the Functionalist educational perspective, the school has the function of transmitting and boosting acceptable behavior and to foster core moral values like respect, truthfulness, loyalty, hard work, responsibility which trains an average student to be useful in the society and be able to contribute in national development like vision 2035 (Promoting Social and Political Integration, promotion of change, and Maintaining Social Control). Some of the major factors that initiate interest in the teaching of ethical education, according to UNESCO (2003) [22], include: rapid changes in scientific output, increased cross cultural contacts, and weakening of national boundaries due to expansion of internet, satellite TV and other media.

Also the aforementioned results of this study, ties with that of Elad (1982) [23] who found that there will be a significant increase in positive attitudes of students towards National integration from primary to secondary and from secondary to post-secondary education; while HE was found a good predictor of national integration, urbanization remained a better predictor of national integration. These are just a few of the possible reasons which explain why ethics and national consciousness was found high in this study especially the fact that, $\mathrm{HE}$ is the most advanced stage where learners gain knowledge, skills and attitude, Peters (1964) [24] and given that almost all the higher institutes of learning are urbanized locations. The fact that the aforementioned result was not close to absolute, is a concern. So for much more better performance and continuity, it is important for civic and ethics education in HE to be taken much more seriously by all stakeholders; a review of textbooks and general curriculum to update current trends and needs guarded towards students' knowledge, skills and attitude should be considered for the absolute attainment of vision 2035 .

Results from the interview revealed that $83.33 \%$ of teachers (10 male and 10 female) usually encourage the promotion of ethics and national consciousness with a common option of sensitizing and teaching of ethical values and national diversities amongst colleagues and to their learners, while 16.67\% (2 male and 2 female) revealed that, they do not encourage the implementation of ethics and national consciousness because it is not part of their teaching subjects/curriculum as such it is a waste of time. This results corroborate with researchers such as (Torney-Purta and Wilkenfeld, 2009 [25]; Gelaneh 2012 [26]) who found that; students who experienced deliberate instruction and interactive discussion-based on civic education had the knowledge and highest scores on a measure of twenty-first century competencies, including economic knowledge, skill in interpreting media, and positive attitudes toward diverse groups, than their peers who lacked such instruction. Also, from the Behaviorist Psychologist 
point of view, "behaviors whether good or bad is learned" which implies that students in HE can learn good or bad behavior depending on the level of effectiveness to implement the stated HEO. Once some teachers start to undermined and neglect the concepts of ethics and national consciousness in teaching-learning process as shown in the results, it may produce some "unintended graduate with deviant behaviors" who will consequently not be a significant factor of contribution to vision 2035 attainment. I therefore like to categorically state that, some factors which may hinder the attainment of Cameroon's vision 2035 in this regard include but not limited to; corruption, embezzlement, laziness, and unpatriotic citizens, who mostly are those untrained and unprofessional graduates from HE to lead public offices. This is because, the Manpower Requirements Approach (MRA) according to Harbison \& Meyer (1964) [27], and (Mbua, 2003) [1], does not only propagate a strong labor force but "Professional Ethics" to enhance the objectives of a given organization or institution. Given that HE by its basic mandate is expected to be producing, organizing and disseminating scientific, cultural, professional and ethical knowledge for development purposes (MINESUP, 2001) [15] the prospective professional graduates, in summary are required to acquire high level of professional ethics suitable for employability. Gulzar cited in Doh (2015) [10] supported this when he maintained that, the main link of education with economic development is through the knowledge, attitude and skills it produces in the labor force. For instance, through the teachings of responsibility, and hard work the "mindset" of students can be effectively changed positively towards poverty alleviation, national unity, patriotism, etc, to get involved in nations development instead of constituting and increasing a dependency ratio, hence the attainment of vision 2035.

Next, results revealed that, the relationship between promotion of bilingualism and Cameroon's vision 2035 with respect to poverty alleviation, and national unity and consolidation of democracy is low. This result therefore means that, with the present state of the promotion of bilingualism, Vision 2035 may not be attained with respect to poverty alleviation and national unity and consolidation of democracy. This results (participants opinion) corroborates with Lafrancios cited in Tambo (2003) [12] and Nsamenang, (2007) [28] who in view of effective teaching and learning augured from the behaviorist perspective that "a teacher can only say teaching has taken place when the learners behavior is seen positively different from the previous behavior" (effective implementation of bilingualism, teaching monolingual learners, transformed to bilingualism graduates). This point to the fact that most potential or graduates from HE in Cameroon are not bilingual enough because of ineffective implantation of the bilingualism. Njeck cited in Echu (2005) [29] found out that $88 \%$ of students interviewed confirm that they have difficulties in following up courses in their second language of learning, and claim that their performances would be better if they were to work solely in their first official language. This explains why graduates from HE are found wanting in the bilingual status for this reason. Suh cited in Tambo (2012) [30] supported this by pointing to the fact that many educational prob- 
lems that the educational systems face is as a result of the problem of preceding from optional and individual bilingualism to institutional bilingualism. This has come to cause a disparity in effective implementation of bilingualism in HE in Cameroon, hence poor performance of graduates in this regards. This is also supported by Doh (2015) [10] after "Evaluating the Strategic Objectives of Cameroonian HE" revealed that there is a general knowledge of the strategic objectives but there is disagreement on the relevance of these objectives to HE and on the type of approaches used in implementing the objectives. At this point, I am tempted to conclude that, the policy and practices of "bilingualism" in Cameroon's HE are contrasting like day and night, and such mismatch in policy and practice is a serious direct threat to attainment of vision 2035. This is because, Article 5 of Law No. 005 of 16 April 2001 to Guide Higher Education in Cameroon states that "in higher education, the State shall ensure that bilingualism is a factor for unity and national integration" and Article 10: (1) of the same law which insist that "The State shall permanently monitor the implementation of rules and regulations in all higher education domains as well as academic and pedagogic activities of all private education institutions". The Shape contrast which exist between policy and practice exist as a result of ineffective teaching of bilingualism, and ineffective monitoring of the HE teaching learning process as stated above. This is supported by Purser (cited in Plessis, 2006) [31] who found that Bilingual universities/education are, mostly a political creations (UNESCOCEPES, 2000) [32] and thus the products of unique contexts, traditions and social conditions. In most cases is the consequence of some kind of political compromise. Similarly, Amin (2002) [33] revealed that, Bilingualism at the University of Yaounde' I (Cameroon) was also derived from a political unity brought about by the amalgamation of the English-speaking southern Cameroon with the then La Re'publique du Cameroun leading to the adoption of two official languages for the new state. Which means, that the promotion of bilingualism in most countries, and Cameroon to be specific, has more of political agenda rather than economic and national development. With a careful observation and analysis of bilingualism orientation laws in Cameroon, one would notice that they are all guarded towards the promotion of bilingualism and linked to vision 2035, at the same time low level of bilingual education from this perspective came as a result of poor implementation and monitoring of HEO. It important to reiterate that bilingualism is one of the main door for graduates employability in Cameroon, promotion of national unity, national dialogue, etc which contributes to national development, as such should not be neglected.

Contrary to students opinions, results from the interview revealed that $70.83 \%$ of teachers ( 8 male and 9 female) said that they usually encourage the promotion of bilingualism with a common option of speaking to and teaching/evaluating the learners in the two official languages (English and French) based on their diversities while $29.17 \%$ ( 4 male and 3 female) revealed that, they do not encourage the implementation of bilingualism because they themselves are not bilingual. They teach using the language they are versed with and do not evaluate 
learners in English and French. The results are in line with Doh (2012) [4] who noted that, the bilingualism in Cameroon implies that teaching takes place in the teachers' first official language (FOL) French or English or second official language as preferred. At the same time, Law No 98/004 of 14 April 1998 section 37 (1) clearly states that, "the teacher shall be the principal guarantor of quality education". This view is supported by Darling, (1992) [34] and Eid (2014) [35] who found that quality teacher is a foundation for quality students (learning outcomes), meaning teachers have a great responsibility when it comes to implementing the HEO. The researcher noted here that, there is big gap in students and teachers' opinion regarding bilingualism implementation. There are high chances that the teachers are not effectively implementing bilingualism as recommended. This is because Law $\mathrm{N}^{\circ} 005$ of $16^{\text {th }}$ April, 2001, Article 37: (1) which stipulated that, the lecturer shall be obliged to teach, educate, supervise pedagogic activities, produce scientific materials, assess academic work and be upright. This implies that, he or she (teacher) should be bilingual to a greater extent to perform this task. Oliveros cited in Mbua (2003) [1], in view of the Manpower requirement approach (MRA) augured that every system needs a required number of Manpower to corroborate to the tasks at hand. In the Cameroon context, bilingualism remains one of the prerequisites for job acquisition and national integration and unity which should ideally translate to economic growth and development yet this study found the implantation of bilingualism low from the perspective of students who are main target of this study. It is interesting to know that, the same graduate from HE will in future recycle themselves into the system to become lecturers, leaders, administrators and policy makers. And because of their inability to communicate in both languages, they will continue to use the language they are most comfortable with to teach students or run affairs, and the situation will go on and on if no major reform is brought into the system. Therefore the promotion of bilingualism must be strengthened in HE. Given that results from this study revealed that the current level of bilingualism is not a significant predictor of the attainment of Cameroon's Vision 2035 with respect to poverty alleviation and national unity and consolidation of democracy, there is a need for effective implementation of this HEO through monitoring and supervision of instruction, so that it paves the way for Vision 2035. With respect to poor implementation of bilingualism Kouega (2006) [36] recommended that bilingual lecture notes be made available to both teachers and students, old teachers be drilled on bilingual teaching and that bilingual proficiency be a determining criterion in future teacher recruitment interviews. Therefore, it is only when a large percentage of HE graduates become bilingual, can they fully integrate into the larger system of Cameroon to explore a variety of opportunities, without being limited to specific area just because they lack proficiency in one language.

Furthermore, results from interviews indicates that $75 \%$ of respondents said that their school encourages poverty alleviation. This is because they offer courses in entrepreneurship, resource management, banking and accountancy 
compulsory to students; as such student will have necessary skills for self-employment. On the contrary $25 \%$ revealed that, their institutions do not encourage poverty alleviation because their institutions do not offer courses in entrepreneurship, resource management, banking and accountancy compulsory to students, as such some student may not have necessary skills for self-employment. This results are in line with Doh (2012) [4] who found out that HE possesses the potential to address countries' specific contexts of poverty depending on the way it embraces the societal preoccupations into its operations. This involves teaching, training, promoting and researching the problems of poverty and in general, that the university should be in the business of understanding what poverty is and tailoring knowledge to build capacities for poverty reduction. At the same time, when some school neglect this aspect, student will graduate require skills and knowledge to fight poverty. In addition Data from the economic and social indicators investigated, reveal that the University of Buea by its very presence has been a significant agent in the development of the municipality (Fongwe, 2010) [37], which means HE has a great role to play in vision 2035 in this regards.

Finally, from interviews results indicates that $83.33 \%$ of respondents said that their school encourages the strengthening of national unity and consolidation of democracy. This is because they encourage the creation of student's association, organizes games, send students on internship, and treat students from different cultural diversity equally. On the contrary, $16.67 \%$ revealed that, their institutions do not encourage the strengthening of national unity and consolidation of democracy because they do not encourage the creation of student's association, organizes games, send students and finally do not treat students from different cultural diversity equally. At the same time, Article 5 of Law No. 005 of 16 April 2001 to Guide Higher Education in Cameroon states that "in higher education, the State shall ensure that bilingualism is a factor for unity and national integration" which makes bilingualism the core national unity. From a similar perspective Doh (2012) [4] noted that with bilingualism, can enhance the peaceful co-existence of Christians and Muslims and the Francophone-Anglophone cultures usually renders Cameroon a potential place of consensus and convergence to host forums (conferences, seminars) and other programmes at the African and international levels. Hence strengthening of national unity and consolidation of democracy is a priority not a choice.

\section{Conclusion}

The inability of most graduates from HIL to prove their skills, knowledge and attitude in the area of professionalism and sustainable development motivated the researcher to carry out this study. The results analyzed indicated that: The Promotion of Ethics and National Consciousness has a significant influenced in the attainment of Cameroon's vision 2035 with respect to poverty alleviation and national unity and consolidation of democracy; The current is Promotion of bilingualism is low, so currently it has an insignificant influenced in the attain- 
ment of Cameroon's vision 2035 with respect to poverty alleviation and national unity and consolidation of democracy. Results also indicates that not only the selected HEO in this study have can contribution to the attainment of Cameroon's Vision 2035. The researcher concluded that, there are so many other factors that will significantly contribute to the attainment of vision 2035. And because HEO implementation do not only end at classroom teaching, monitoring and close supervisions are encouraged for effective implementation.

\section{Limitation}

In terms of content scope, this study was limited to two the higher education objectives and two objectives of Cameroon's vision 2035. While the context was limited to one (1) out of ten (10) regions in Cameroon. Thereby focusing on a few schools and a relatively small target population, which limits the findings from being generalizable to a larger extent. This served as one of the main limitation of this study because the other HEO, visions 2035 objectives, and other regions which were not part of this study might have more results to explain how "Higher Education Objectives are Impacting the Attainment of Cameroon's Vision 2035". This also means that, there are probably many other factors that will significantly contribute to the attainment of vision 2035 but were not explored in this study. Therefore further researches can explore, most of the HEO, visions 2035 objectives, and regions which were not part of this study, to be able to give a clear picture on the aforementioned relationship.

\section{Recommendations}

From the findings of this study the following recommendations are made:

- All teachers should respect the HEO while implementing the curriculum so that the student will gain the required skills, attitude and knowledge, hence professionals in their different domains so as to effectively contribute to Cameroon's vision 2035.

- Given that Bilingualism is a core priority for Cameroon's vision 2035 English and French should be a prerequisite for teachers' employability especially in bilingual HIL because it will be needed for classroom teaching, student research supervision, conference attendances and presentation, etc. this will help to strengthen bilingualism.

- Strategic and meaningful seminars/workshops should be frequently organized by higher institutes of learning (HIL) and ministry of higher education to enhance teachers' professional development on one hand, and students' growth on the other.

- HIL administrators in HIL should directly and indirectly monitor and supervise instructions effectively, and sanction teachers who are not implementing the $\mathrm{HEO}$ as required, put up good leadership practices that will encourage a good learning environment.

- The ministry of higher education/Policies Maker(s) should effectively enforce 
and monitor the implementation of HEO to close most of the gaps which exist in implementation. They should regularly organize Seminars/workshops to train and orientate teachers towards the implementation of stated objectives. They should provide necessary resources to enhance this in implementation, for example provision of research institutes, invest in teachers' professional development, equipped libraries, train and supply qualified teachers, effective supervision of instruction, pay regularly research grants to researchers for motivation etc.

\section{Conflicts of Interest}

The author declares no conflicts of interest regarding the publication of this paper.

\section{References}

[1] Mbua, F.N. (2003) Educational Administration: Theory and Practice. Design House, Limbe.

[2] Ojong, T.T. (2008) Philosophical and Historical Foundations of Education in Cameroon 1844-1960. Design House, Limbe.

[3] World Bank (2009) The East Asian Miracle. Oxford University Press, New York.

[4] Doh, P.S. (2012) The Responses of the Higher Education Sector in the Poverty Reduction Strategies in Africa: The Case of Cameroon. Doctoral Dissertation, Acta Universitatis Tamperensis 1755, Tampere University Press, Tampere.

[5] United Nations (2015) Transforming Our World. The 2030 Agenda for Sustainable Development.

https://sustainabledevelopment.un.org/post2015/transformingourworld/publication

[6] UNESCO (1998) Higher Education in the Twenty-First Century: Vision and Action. United Nations Educational, Scientific and Cultural Organization, Paris.

[7] SUP INFOS (2010) A Bilingual Quarter Review of Higher Education in Cameroon. No. 14, Ministry of Higher Education, Yaoundé, Cameroon.

[8] Ngwane, G.M. (2009) Vision 2035: Rebranding Cameroon. https://www.gngwane.com/2009/04/cameroun-vision-2035-rebranding-cameroon.h $\underline{\mathrm{tml}}$

[9] Meek, A. (1993) On Setting the Highest Standards: A Conversation with Ralph Tyler. Educational Leadership, 50, 83-86.

[10] Doh, B.T.S. (2015) Evaluating the Strategic Objectives of Cameroonian Higher Education: An application of the Balanced Scorecard. JUVENES PRINT-Suomen Yliopistopaino Oy, Turku. https://www.researchgate.net/publication/279040912

[11] Fonkeng, G.E. (2007) The History of Education in Cameroon, 1884-2004. The Edwin Mellen Press, Lewiston.

[12] Tambo, L.I. (2003) Cameroon National Education Policy since the 1995 Forum. Design House, Limbe.

[13] MINEDUC (1998) Law No. 98/004 of 14 April to Lay down Guidelines for Education in Cameroon.

[14] Tchombe, T.M. (2001) Structural Reforms in Education in Cameroon. http://www.unifr.ch/ipg/ecodoc/conferences/DocuPDFConfInter/Tchombe.pdf

[15] MINESUP (2001) Law No. 005 of 16 April 2001 to Guide Higher Education. Minis- 
try of Higher Education, Cameroon

[16] MINEPAT (2009) Growth and Employment Strategy Paper: Reference work for Government Action over the Period 2010-2020. Ministry of Economy, Planning and Land Planning, Cameroon.

[17] GESP (Growth and Employment Strategy Paper) (2009) Reference work for government action over the Period 2010-2020. MCG.RAW. Hill, Inc., New York

[18] Amin, M.E. (2005) Social Science Research: Conception, Methodology and Analysis. Makerere University, Kampala

[19] Krejcie, R.V. and Morgan, D.W. (1970) Determining Sample Size for Research Activities. Educational and Psychological Measurement, 30, 607-610. https://doi.org/10.1177\%2F001316447003000308

[20] Mbiko, S.A. (1990) A Handbook on Research Methods. Etukokwu Publishers (NIG) Ltd., Onisha Nigeria

[21] Ndongko, T.M. and Tambo, L.I. (2000) Educational Development in Cameroon 1961-1999 Issues and Perspectives. United State of America: Modison Wisdom Publishers Ltd.

[22] UNESCO (2003) Report of the Working Group on the Teaching of Ethics. World Commission on the Ethics of Scientific Knowledge and Technology, COMEST, France. https://unesdoc.unesco.org/ark:/48223/pf0000134552

[23] Elad, G.M. (1982) Schooling and National Integration in Cameroon. Thesis Submitted in Fulfilment of the Requirements for the Degree of Doctor of Philosophy in the Institute of Education. University of London, London.

[24] Peters, R.S. (1964) Ethics and Education. London University Press.

[25] Torney-Purta, J. and Wilkenfeld, B. (2009). Paths to 21st Century Competencies through Civic Education Classrooms. American Bar Association Division for Public Education, Chicago.

[26] Gelaneh, B.J. (2012) The Role of Civics and Ethical Education in the Development of Students' behavior: The Case of Kokebe Tsibiha Secondary and Preparatory school. A Thesis Submitted to Institute of Educational Research. Addis Ababa University, Addis Ababa, Ethiopia

[27] Harbison, F. and Meyer, A. (1964) Education Manpower and Economic Growth. Mac Growhill Book Company, New York.

[28] Nsamenang, A.B. (2007) The Teaching Learning Transaction. Anoh's Printing Service, T-Junction, Bamenda.

[29] Echu, G. (2005) The Immersion Experience in Anglophone Primary Schools in Cameroon. ISB4. In Cohen, J., McAllister, K., Rolstad, K., MacSwan, J., Eds., Proceedings of the 4th International Symposium on Bilingualism, Somerville, 30 April-3 May 2003, 643-655.

[30] Tambo, L.I. (2012). Principles and Methods of Teaching. Application in Cameroon Schools. Design House, Limbe.

[31] Plessis, T.D. (2006) From Monolingual to Bilingual Higher Education: The Repositioning of Historically Afrikaans-Medium Universities in South Africa. Language Policy, 5, 87-113. https://doi.org/10.1007/s10993-005-5627-5

[32] UNESCO-European Centre for Higher Education (2000) The Bilingual University-Its Origins, Mission, and Functioning. Report on an Invitational Seminar, UNESCO European Centre for Higher Education, Bucharest, Romania.

[33] Amin, M.E. (2002) Six Factors of Course and Teaching Evaluation in a Bilingual 
University in Central Africa. Assessment \& Evaluation in Higher Education, 27, 281-291. https://doi.org/10.1080/02602930220138633

[34] Darling, H.L. (1992) Teacher Quality and Students Achievement: A Review of State Policy Evidence. Standford University Press.

[35] Eid, F.H. (2014) Research, Higher Education and the Quality of Teaching: Inquiry in a Japanese Academic Context Higher Education Council, Kingdom of Bahrain. Research in Higher Education Journal, 24, 1-25.

[36] Kouega, J. (2008) Bilingualism at Tertiary Level Education in Cameroon: The Case of the University of Yaoundé II (Soa). Proceedings of the 6 th International Symposium on Bilingualism, Hamburg, 30 May-2 June 2007.

http://archiv.gwin.gwiss.uni-hamburg.de/isb6/proceedings/kouega.pdf

[37] Fongwe, N.S. (2010) The Contribution of Higher Education to Regional Socio Economic Development: The University of Buea, Cameroon, as a Growth Pole. A Thesis Submitted to University of the Western Cape, Cape Town. 